\title{
PENGAPLIKASIAN PEMBELAJARAN BERBASIS KEHIDUPAN GUNA MENDUKUNG AKTIVITAS BELAJAR
}

\author{
APPLICATION OF LIFE-BASED LEARNING TO SUPPORT \\ LEARNING ACTIVITIES
}

\author{
Zahid Zufar At Thaariq \\ Mahasiswa Program Studi Teknologi Pendidikan, Fakultas Ilmu Pendidikan, Universitas Negeri Malang; \\ Email: zahid.thoriq.1701216@students.um.ac.id
}

Dikirim 22 April 2021, Direvisi 12 Juni 2021, Disetujui 29 Juli 2021

\begin{abstract}
Abstrak: Teknologi Informasi dan Komunikasi (TIK) telah mengalami perkembangan yang begitu pesat, sehingga menyebabkan terjadinya berbagai perubahan di segala bidang, khususnya pendidikan. Pendidikan merupakan kunci dasar dari pembangunan sumber daya manusia. Maka, salah satu kunci dari pendidikan yang berkualitas terletak pada penerapan proses belajar mengajar yang dilakukan. Penerapannya pada saat ini dapat dibilang sangat memiliki potensi yang besar. Hal ini dikarenakan dengan adanya bantuan TIK, berbagai akses untuk belajar yang cenderung tidak terbatas. Bekal ini menjadi sangat penting dalam memberdayakan pebelajar yang berkualitas dan unggul. Untuk itu, penulis tertarik mengkaji tentang life-based learning (pembelajaran berbasis kehidupan) sebagai solusi dalam mendukung aktivitas belajar di era keterbukaan saat ini. Perlu untuk diketahui bahwa life-based learning merupakan konsep belajar yang menekankan pada kehidupan yang sebenarnya, jadi tidak hanya berorientasi pada pembelajaran yang bersifat statis, namun juga dinamis serta temporer. Harapannya melalui tulisan ini dapat menjadi suatu alternatif referensi dalam pengembangan pembelajaran ataupun pengembangan penelitian berikutnya.
\end{abstract}

Kata kunci: Pembelajaran Berbasis Kehidupan, Konstruktivisme, Aktivitas Belajar

\begin{abstract}
Information and Communication Technology (ICT) has experienced rapid development, causing various changes in all fields, especially education. Education is the basic key of human resource development. So, one of the keys to quality education lies in the application of the teaching and learning process that is carried out. The application at this time can be said to have great potential. This is because with the assistance of ICT, various accesses to learning tend to be unlimited. This provision is very important in empowering qualified and superior students. For this reason, the authors are interested in studying life-based learning as a solution in supporting learning activities in the current era of openness. It is necessary to note that life-based learning is a learning concept that emphasizes real life, so it is not only oriented towards learning that is static, but also dynamic and temporary. The hope is that through this paper it can be an alternative reference in the development of learning or subsequent research development.
\end{abstract}

Keywords: Life-based Learning, Constructivism, Learning Activities

\section{PENDAHULUAN}

Era keterbukaan saat ini menawarkan beragam kemudahan di segala bidang. Mulai dari berkomunikasi, melakukan pencarian dan sebagainya. Hal tersebut menjadikan informasi sebagai bagian yang tidak terpisahkan dari kebutuhan masyarakat Indonesia. Informasi menjadi hal penting yang setara dengan makanan sehari-hari. Informasi telah menjadi alat bagi masyarakat untuk mengambil keputusan baik bagi individu maupun organisasi resmi. Tanpa informasi tertentu, pengambilan keputusan tidak akan mendapatkan hasil yang maksimal (Prasetiawan, 2012). Hal ini diperkuat lagi dengan fenomena pandemi COVID-19 yang telah merubah segala bidang, khususnya dalam bidang pendidikan yang kini serba digitalisasi.

Perubahan pada era ini tidak dapat dihindari oleh siapapun, sehingga diperlukan penyiapan sumber daya manusia (SDM) yang memadai untuk siap menyesuaikan diri dan mampu bersaing dalam skala global. Peningkatan kualitas sumber daya manusia mulai dari pendidikan dasar dan menengah hingga perguruan tinggi menjadi kunci untuk dapat 
mengikuti perkembangan zaman (Lase, 2019). Kemunculan teknologi digital dan penetrasinya ke semua jenjang pendidikan, dari taman kanak-kanak hingga universitas, telah menantang institusi pendidikan tinggi untuk mendefinisikan kembali praktik pembelajaran dan penelitian mereka serta mendesain ulang infrastruktur organisasi mereka. Teknologi digital diterapkan dalam proses belajar mengajar untuk berbagai tujuan, yakni pencarian informasi dari berbagai sumber, simulasi dan presentasi multimedia, komunikasi dengan pengajar saat dan sesudah kelas, komunikasi di antara pebelajar, melakukan latihan dan uji sampel, administrasi kelas dan sebagainya (Guri-Rosenblit, 2009).

Kehidupan banyak orang sekarang diatur oleh smartphone, tablet, Wi-Fi, dan persyaratan lain untuk 'selalu aktif'. Demikian pula, sekolah, perguruan tinggi, dan universitas dibanjiri perangkat digital, dan semakin banyak pekerjaan pendidikan yang dilakukan dengan basis 'virtual'. Namun di tengah konotasi 'transformatori' dan 'mengganggu' dari perkembangan ini, 'era digital' menandai kelanjutan dari sejumlah ketegangan pendidikan yang sudah berlangsung lama. Ini termasuk masalah ketidaksetaraan dan eksklusi; perbedaan kekuasaan dan hubungan sosial yang tidak setara; korespondensi yang tidak muda, antara pendidikan dan ekonomi (global) dan privatisasi serta komersialisasi layanan publik (Selwyn, 2014).

Akibatnya, sekolah dan universitas menghadapi tantangan baru. Dalam ekonomi industri lama negara maju, lulusan yang telah menguasai keterampilan dasar dalam membaca, menulis, dan matematika mampu menemukan pekerjaan yang baik. Tetapi anak-anak muda di negara-negara seperti saat ini perlu berpikir bukan tentang pekerja jalur perakitan, namun lebih seperti profesional yang memecahkan masalah yang tidak memiliki jawaban mudah. Mereka perlu belajar penilaian dan kebijaksanaan daripada kepatuhan. Keterampilan yang pernah menjadi pelestarian elit semakin menjadi prasyarat untuk pekerjaan tingkat pemula dalam bentuk apapun. Di era digital persaingan global, sekolah dan universitas harus melatih anak muda untuk berpikir kreatif, kolaborasi, dan pemecahan masalah yang kompleks (Shaffer, 2008).

Maka dari itu, untuk mengakomodasi kebutuhan terhadap keterampilan tersebut, diperlukan cara-cara baru yang dapat membangun diri pebelajar baik secara langsung maupun tidak langsung dengan penerapan pembelajaran yang berbeda dari sebelumnya. Pendekatan yang konvensional sudah dianggap "usang" dan perlu diganti dengan pendekatan baru yang dapat membangun aktivitas belajar dari pebelajar. Untuk itu, penulis tertarik untuk menelaah life-based learning (pembelajaran berbasis kehidupan) sebagai salah satu solusi yang dapat diterapkan guna memaksimalkan potensi digital untuk pembelajaran. Pada telaah ini akan membahas (1) perubahan paradigma belajar, (2) konsep life-based learning beserta pengaplikasiannya dan (3) implementasi life-based learning berdasarkan penelitianpenelitian sebelumnya yang pernah dilakukan.

\section{METODOLOGI}

Penyusunan ini menggunakan metode penelitian berupa tinjauan literatur. Tinjauan literatur penelitian adalah metode sistematis, eksplisit, dan reproduksi untuk mengidentifikasi, mengevaluasi, dan mensintesis tulisan-tulisan yang diproduksi oleh para peneliti, cendekiawan, dan praktisi (Fink, 2019). Tinjauan literatur berusaha mengintegrasikan apa yang telah dilakukan dan diucapkan orang lain, memberikan kritik terhadap karya ilmiah sebelumnya, membangun jembatan di antara bidang topik terkait, mengidentifikasi masalah pusat dalam sebuah penelitian, atau semua ini (Cooper, 1998).

Dalam menyusun artikel ini penulis melakukan beberapa langkah-langkah, yakni (1) pencarian dan pengumpulan datadata berupa literatur-literatur dari berbagai 
sumber, (2) analisis literatur dan teori-teori yang berkaitan, (3) mendeskripsikan hasil dari analisis dan (4) menggambarkan kesimpulan. Dalam menyusun kesimpulan, penulis mempertimbangkan beberapa aspek yang diantaranya (1) perkembangan zaman yang semakin pesat, (2) generasi pebelajar yang memasuki era yang tidak memiliki batasan, (3) perlunya kesiapan pebelajar dalam menghadapi tantangan zaman dan (4) kesiapan pembelajaran di era yang terbuka.

\section{HASIL DAN PEMBAHASAN}

\section{Paradigma Belajar menuju Konstruktivistik}

Ungkapan dulu yang sering terdengar dalam telinga adalah "pasal 1 guru selalu benar, pasal 2 apabila guru salah dikembalikan lagi ke pasal 1". Arah angin selalu berubah. Tidak ada yang abadi dalam kehidupan di dunia. Perlu menjadi kajian bersama bahwa kelemahan pembelajaran saat ini yang masih dipandang sebagai kegiatan yang mekanikal tidak dapat diterapkan di semua bidang pembelajaran. Kemerdekaan berpikir para ilmuwan dan praktisi pendidikan adalah "gugatan" terhadap pemberdayaan kepada pebelajar. Pembelajaran harus menjadi student centered learning (Praherdhiono, Adi, \& Prihatmoko, 2020). Pembelajaran di era pandemi merupakan pembelajaran untuk membangun pemikiran tanpa harus melakukan pertemuan-pertemuan secara fisik, sedangkan pasca pandemi covid-19 merupakan pembelajaran personal dan pembelajaran secara sosial dimana individu telah menjadi sosok yang matang dalam konsep diri (Praherdhiono dkk., 2020). Maka, perlu adanya perubahan suatu paradigma belajar untuk menghadapi hal tersebut.

Banyak kajian penelitian yang membahas paradigma konstruktivistik sebagai suatu paradigma yang akan menggantikan pembelajaran tradisional. Pembelajaran tradisional kental dengan guru sebagai pusat sumber belajar (teacher- centered learning). Guru menjadi penguasa penuh dan tidak memberikan variasi pembelajaran yang dilakukannya. Pembelajaran secara tradisional diklaim menghasilkan pengetahuan inert pada siswa, pengetahuan yang dapat digunakan dalam pengaturan pendidikan seperti mempersiapkan tes dan ujian, tetapi tidak dapat ditransfer ke dalam situasi kehidupan nyata (Tynjälä, 1999). Dalam kelas tradisional, pembelajaran secara terbuka merupakan aktivitas yang pasif dan secara berurutan yang diarahkan oleh guru (Byers, Imms, \& Hartnell-Young, 2018). Pendekatan pembelajaran tradisional yang terus menjadi alat pembelajaran yang lazim, sering dikritik sebagai cara yang tidak efektif untuk belajar mengajar (Bazelais \& Doleck, 2018). Maka, paradigma konstruktivistik ini berbicara hal yang sebaliknya.

Konstruktivisme rasional adalah teori terkemuka dalam psikologi perkembangan. Ini bertujuan untuk mendeskripsikan mekanisme psikologis yang memandu pembentukan pengetahuan awal pebelajar tentang dunia fisik dan sosial mereka (Fedyk \& Xu, 2018). Konstruktivisme melihat dunia, dan apa yang dapat kita ketahui tentang dunia, sebagai konstruksi sosial. Pandangan ini mengacu pada hakikat realitas dan hakikat pengetahuan yang disebut juga ontologi dan epistemologi dalam bahasa penelitian (Theys, 2017).

Konstruktivisme adalah teori belajar yang mempersepsikan belajar sebagai proses membangun pengetahuan berdasarkan pengalaman (Jumaat, Tasir, Halim, \& Ashari, 2017). Paradigma konstruktivisme memiliki beberapa pandangan yang diantaranya sebagai berikut (Degeng, 1998).

1. Pengetahuan adalah non-objective, bersifat temporer, selalu berubah dan tidak menentu.

2. Belajar merupakan upaya penyusunan pengetahuan dari pengalaman konkrit, aktivitas 
kolaboratif dan refleksi serta interpretasi

3. Mengajar adalah menata lingkungan agar pebelajar termotivasi dalam menggali makna serta menghargai ketidakmenentuan.

4. Pebelajar akan memiliki pemahaman yang berbeda tergantung dari pengalamannya serta perspektif yang dipakai dalam menginterpretasikannya.

5. Pembelajaran yang berorientasi pada proses.

Konstruktivisme adalah pendekatan populer dalam merancang lingkungan belajar. Konstruktivisme adalah pandangan belajar bahwa siswa secara aktif membangun pengetahuan dan belajar berdasarkan interaksi mereka dengan lingkungannya. Dalam pendekatan konstruktivis, pembelajaran berlangsung bukan karena pemindahan pengetahuan dari guru kepada siswa melalui teks atau basis pengetahuan pribadi, tetapi karena siswa menafsirkan dan memahami lingkungannya (Anagün, 2018).

\section{Pengaplikasian Life-based Learning: MOOCs, LMS dan Media Sosial}

Sebuah adaptasi perlu untuk segera "digalakkan" dalam proses pembelajaran. Generasi baru yang lahir di bawah 2000-an merupakan generasi yang begitu cerdas dan aktif dalam memanfaatkan perangkat yang dimilikinya untuk digunakan untuk "berselancar" hingga mencari hal baru yang bahkan tidak pernah terpikirkan oleh kita sebelumnya. Pembelajaran yang mengutamakan guru sebagai pusat sumber informasi sudahlah tidak mungkin untuk membendung kecerdasan dan keaktifan yang dimiliki oleh generasi baru ini. Guru memiliki tugas utama dalam pembelajaran, yakni (1) merancang, (2) melaksanakan dan (3) menilai (Gagne, 1985). Tugas merancang dilakukan sebelum pelaksanaan kegiatan di dalam kelas, yaitu merencanakan seluruh aktivitas yang dilakukan agar terjadinya proses belajar bagi pebelajar. Tugas mengajar sangat berkaitan dengan tugas-tugas mengembangkan tiga aspek utama, yang oleh Bloom diidentifikasi sebagai aspek atau matra kognitif, psikomotorik dan afektif. Ketiga aspek ini merupakan dimensi olah pikir, dimensi olah raga dan dimensi olah rasa (Setyosari, 2017). Dalam kaitan dengan tugas ketiga, yaitu menilai keseluruhan aktivitas yang telah dirancang dan dilakukan yang dalam hal ini berupa program pembelajaran. Penilaian ini mencakup penilaian proses dan hasil, yaitu mulai dari kegiatan perencanaan, proses kegiatan pembelajaran hingga hasil yang ditentukan (Setyosari, 2017).

Life-based learning (Pembelajaran berbasis Kehidupan) merupakan salah satu bentuk dukungan pembelajaran yang memiliki efektivitas baik saat dirancang, dilaksanakan maupun dinilai. Life-based Learning adalah proses memperoleh pengetahuan dan keterampilan untuk memahami hakikat kehidupan, terampil memecahkan masalah kehidupan, menjalani kehidupan yang seimbang dan harmonis. Life-based Learning menyajikan konsep bahwa belajar dari kehidupan adalah pembelajaran yang nyata. Sekolah sejati bagi manusia adalah kehidupan atau pengalaman hidup mereka sendiri (Hidayat, Patmanthara, Sari, \& Sutikno, 2019). Kehidupan nyata, sebagaimana dipelajari oleh psikologi pendidikan, individu merupakan pemilik hidupnya. Penyesuaian kepemilikan hidup sangat tergantung pada pebelajar individu. Pemikiran manusia adalah individu dan makhluk sosial adalah kunci untuk belajar. Setiap individu akan belajar jika lingkungan belajarnya mendukung (Praherdhiono, 2019).

Maka, dapat diambil sebuah intisari bahwa life-based learning merupakan konsep pembelajaran yang menggunakan pengalaman dan kehidupan nyata sebagai sumber belajar. Pembelajaran ini menitikberatkan pada pengembangan kapabilitas (kemampuan dan kemauan) seseorang untuk memenuhi seluruh kebutuhan hidupnya (Ratnawati \& Setuju, 
2019). Pembelajaran berbasis kehidupan ini dapat memberikan untuk mengembangkan kemampuan individu. Dalam pembelajaran ini juga menjadikan pebelajar memiliki kemauan penuh untuk memenuhi kebutuhannya baik dalam pembelajaran maupun dalam pembelajaran sosial untuk bekerja dan tidak dibatasi oleh tempat kerja yang merupakan ciri dari pendekatan pembelajaran hidup (Kastur \& Riyanto, 2020).

Tabel 1. Transformasi pembelajaran tersegmentasi menjadi pembelajaran terintegrasi (Staron, 2011a)

\begin{tabular}{|c|c|c|}
\hline $\begin{array}{c}\text { Expert } \\
\text { Centred }\end{array}$ & Work Based & Life Based \\
\hline Pelatihan & $\begin{array}{c}\text { Pengembangan } \\
\text { Profesional }\end{array}$ & $\begin{array}{c}\text { Pengembangan } \\
\text { Kapabilitas }\end{array}$ \\
\hline $\begin{array}{c}\text { Metafora } \\
\text { Hirarki }\end{array}$ & Metafora Jaringan & $\begin{array}{c}\text { Metafora Ekologi } \\
\text { Belajar }\end{array}$ \\
\hline $\begin{array}{c}\text { Pebelajar } \\
\text { adalah } \\
\text { Penerima } \\
\text { yang Pasif }\end{array}$ & $\begin{array}{c}\text { Pebelajar adalah } \\
\text { Pekerja }\end{array}$ & $\begin{array}{c}\text { Pebelajar sebagai } \\
\text { Manusia yang Utuh }\end{array}$ \\
\hline Strategi & Strategi & Orientasi \\
\hline
\end{tabular}

Pembelajaran berbasis kehidupan merupakan salah satu pilar dari paradigma yang dikembangkan oleh UNESCO (Suryati dkk., 2020). Paradigma ini terkait dengan pembentukan kapabilitas pebelajar yang terkandung dalam kecakapan hidup. Jika pebelajar memiliki kecakapan hidup yang baik, mereka akan siap dan praktis dalam menghadapi permasalahan hidup. Tekanan di lingkungan dapat diatasi secara proaktif dan kreatif. Kapabilitas tersebut diantaranya (1) mampu menyeimbangkan antara pengetahuan, pekerjaan, dan studi, (2) dapat melakukan penelitian, (3) dapat langsung menangkap kecakapan hidup, (4) dapat mengaitkan masalah dengan kecakapan Kehidupan yang tergabung (5) dapat menyelesaikan masalah dalam konteks baru (6) mampu menyeimbangkan produktivitas dan kreativitas (7) mampu melakukan adaptasi antara lingkungan langsung dan virtual (Kuswandi dkk., 2020).

Oleh karena itu diperlukan sistem pembelajaran agar belajar tidak hanya terbatas pada kompetensi lapangan, tetapi mampu membangun konstruksi pemikiran modern dengan membangun koneksi keilmuan dalam ekologi pembelajaran. Sistem ekologi pembelajaran yang dibangun harus memungkinkan bahwa semua pembelajaran saling terkait sehingga tidak mudah untuk memisahkan

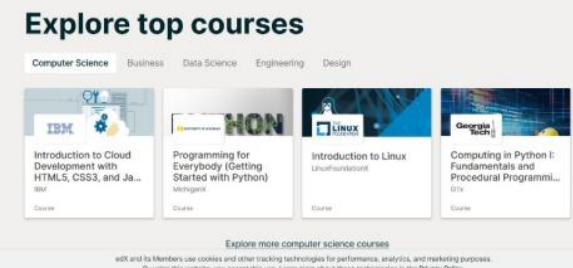

pembelajaran dalam kompetensi bidangnya dari pengetahuan lain seperti orang dewasa dalam pembelajaran (Sulton, 2019).

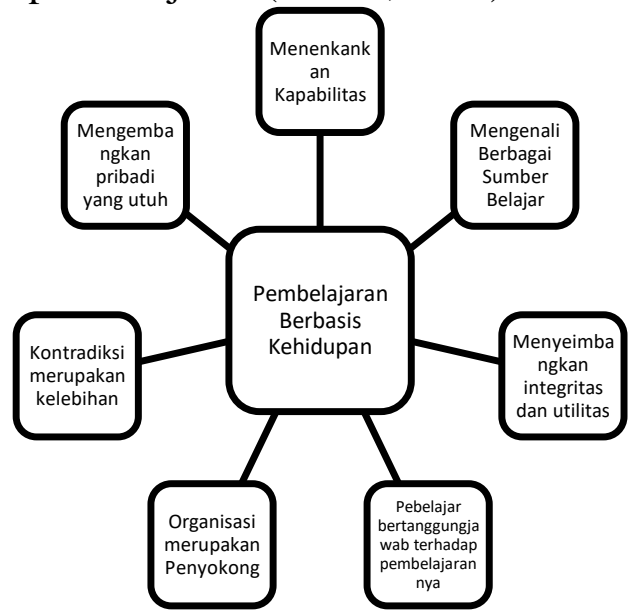

Gambar 1. Karakteristik Pembelajaran Berbasis Kehidupan (Staron, 2011)

Kebutuhan akan berbagai sumber belajar yang dapat membuka peluang untuk mengembangkan kapabilitas dari pebelajar. Tantangannya adalah bagaimana memanfaatkan pendekatan yang lebih terbuka ini untuk kepentingan pelajar dan organisasi. Karena batasan antara bekerja dan belajar semakin kabur, ada kebutuhan untuk memiliki pendekatan pembelajaran yang lebih positif dan holistik. Ini termasuk kebutuhan akan keseimbangan yang lebih besar antara kreativitas dan standarisasi, inovasi dan keseragaman, kontrol dan sistem pengorganisasian mandiri yang terbuka (Staron, 2011b). Orientasi belajarnya didasarkan pada kemampuan pebelajar untuk belajar secara 
komprehensif untuk tumbuh kembang individu dan organisasi individu (Sulton, Adi, \& Susilo, 2017). Dalam kehidupan saat ini, kapanpun dan dimanapun orang dapat belajar. Belajar adalah kebutuhan mendasar setiap manusia (Praherdhiono, Sulton, Lioe, \& Hammad, 2017)

Gambar 2. Pemanfaatan edX (MOOC's) sebagai bagian life-based learning (sumber: edx.org)

Contoh dalam penerapan pembelajaran berbasis kehidupan salah satunya pemanfaatan beberapa platform untuk digunakan sebagai sumber belajar. Penulis mencontohkan dari pemanfaatan Massive Open Online Courses (MOOCs). MOOCs sering dirilis oleh platform online pihak ketiga dan dikembangkan secara independen oleh akademisi. Sejarah MOOCs tidak terlalu jauh. Istilah ini pertama kali muncul pada tahun 2008 oleh Stephen Downes dan George Siemens dan berdasarkan model pembelajaran sejawat yang didistribusikan oleh 'connectivist'. Setelah itu, pada tahun 2011, beberapa video pendidikan lagi dikembangkan oleh para profesor dari Universitas Stanford dan dirilis melalui platform online terbuka yang didukung dengan sumber daya web yang gratis. Ini adalah tahun di mana MOOC menjadi 'meledak' di seluruh dunia dikarenakan jumlah penggunanya yang meluas setiap hari semakin banyak (Baturay, 2015).

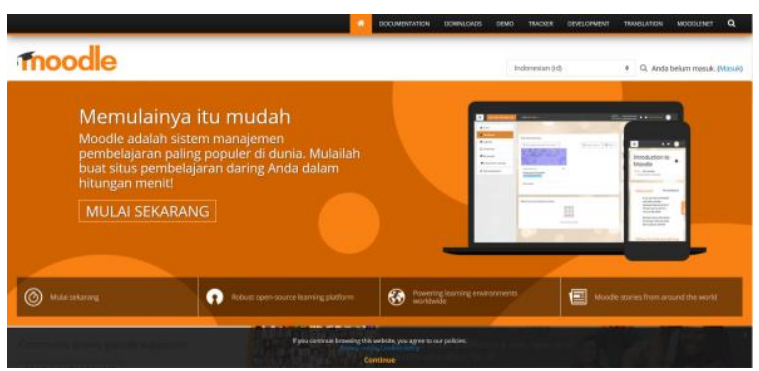

Gambar 3. Moodle sebagai bentuk konstruk LMS yang paling populer (Sumber: moodle.org)

Di samping itu, Learning Management System (LMS) juga digunakan sebagai saluran yang mendukung life-based learning. Learning Management Systems (LMS) adalah teknologi yang berkembang di masyarakat saat ini, yang menyediakan penciptaan kursus, pengiriman, manajemen, pelacakan, pelaporan, dan penilaian materi pembelajaran online. Ini adalah aplikasi perangkat lunak terpusat yang digunakan untuk menggabungkan fitur pedagogis dengan lingkungan pembelajaran virtual. Dengan cara ini, pebelajar dapat menggunakan perangkat pribadi seperti ponsel dan tablet untuk mengakses sumber daya, mengunggah tugas, mengikuti tes, dan berbagi informasi dengan rekan-rekan dan pengajar sehingga menciptakan lingkungan belajar yang dinamis (Mershad \& Wakim, 2018). LMS menyediakan berbagai alat dan fungsi untuk mendukung belajar mengajar, termasuk alat manajemen kelas, obrolan dan diskusi grup online, pengumpulan pekerjaan rumah dan penilaian, dan evaluasi kelas. Beberapa fitur LMS lebih canggih secara teknis, seperti mengadakan jam kerja virtual, mengingatkan pebelajar tentang tenggat waktu, dan membagi siswa ke dalam grup untuk proyek online (Yueh \& Hsu, 2008).

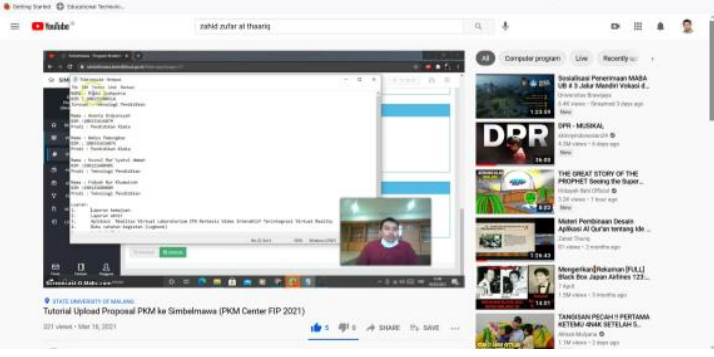

Gambar 4. Pemanfaatan media sosial sebagai bagian life-based learning

Sumber belajar lain yang dapat dimanfaatkan adalah media sosial. Perlu untuk disadari, media sosial telah "merenggut" hati sebagian besar masyarakat, khususnya di Indonesia. Karena media sosial memudahkan untuk diakses dimana saja, kapan saja, dan oleh siapapun yang terhubung. Ini memudahkan pengguna untuk menggunakannya. Berdasarkan data dari Asosiasi Penyelenggara Jasa Internet Indonesia menunjukkan 15 persen dari jumlah penduduk di Indonesia merupakan pengguna internet (Kompas Cyber Media, 2019). Akses yang paling umum digunakan 
adalah media sosial, mengingat dari data Hootsuite Social Media jumlah pengguna media sosial di Indonesia diperkirakan mencapai 150 juta $(56 \%)$. Lebih lanjut, jumlah pengguna media sosial seluler telah mencapai $48 \%$ dari total populasi (Thaariq, 2020). Era informasi yang dibawa oleh perubahan internet telah membentuk dunia media sosial atau media baru. Media sosial telah menciptakan dunia baru yang mengubah tatanan informasi, komunikasi, dan interkonektivitas yang tidak dapat diaktifkan dengan metode tatap muka di kalangan pebelajar (Chukwuere \& Chukwuere, 2017). Maka, media sosial juga dapat dikatakan sebagai lahan potensial, khususnya apabila digunakan untuk belajar untuk mendukung pembelajaran berbasis kehidupan.

Pembelajaran berbasis kehidupan tidak membuang model pembelajaran yang secara tradisional menginformasikan pengembangan kapabilitas yaitu model pembelajaran yang berpusat pada ahli dan model pembelajaran berbasis kerja. Pembelajaran berbasis kehidupan dibangun di atas mereka untuk memperluas kemungkinan pembelajaran untuk pengembangan kemampuan. Strategi dapat bersumber dari model apa pun yang sesuai untuk individu - baik yang berpusat pada ahli, berbasis pekerjaan, atau melalui pengalaman hidup. Tujuannya adalah untuk mengintegrasikan yang terbaik dari ketiga pendekatan tersebut (Staron, 2011b).

\section{Implementasi Life-based Learning dalam Menunjang Aktivitas Belajar}

Masyarakat Indonesia secara tak disadari, telah menerapkan life-based learning pada aktivitas-aktivitas kehidupan sehari-harinya. Penulis dalam membangun kemampuan diri juga melalui aktivitas kehidupan yang penulis lakukan, termasuk melalui internet salah satunya. Banyak juga dari kalangan yang terkenal juga memanfaatkan internet untuk menciptakan suatu ketenarannya. Hal inilah yang menjadi jawaban mengapa life-based learning perlu untuk diterapkan.
Terdapat beberapa penelitian sebelumnya yang memberikan penjelasan dalam penerapan life-based learning. Penelitian dari Praherdhiono, Adi, \& Prihatmoko (2018) yang melakukan riset life-based learning di Jurusan Teknologi Pendidikan, Universitas Negeri Malang dengan menggunakan MOOC dan LMS menunjukkan bahwa mahasiswa secara bebas mengungkapkan pemikirannya dalam bentuk tulisan (bukan pilihan). Infrastruktur online memberikan peluang bagi penyelenggaraan pembelajaran online dan berbasis terbuka. Penelitian telah menunjukkan kesamaan konstruksi pembelajaran yang secara umum sama dengan hasil penelitian MOOC dan LMS.

Penelitian lain yang dilakukan oleh Andayani, Al-Idrus, \& Purwoko (2019) yang melakukan riset yang berkenaan praktikum berbasis kehidupan menunjukkan adanya pengaruh yang positif terhadap keterampilan proses sains siswa, dibandingkan dengan metode praktikum konvensional (berbasis laboratorium). Perbedaan ini disebabkan karena pembelajaran dengan pendekatan saintifik yang dipadukan dengan metode praktikum berbasis kehidupan sehari-hari menciptakan pembelajaran yang lebih bermakna bagi siswa. Perlu untuk diketahui, praktikum berbasis kehidupan sehari-hari merupakan rangkaian tindakan untuk melakukan percobaan dengan bahan dan alat yang mudah didapat di lingkungan alam sekitar siswa dan murah sehingga dapat dijadikan alternatif yang baik untuk dilakukan secara terus menerus (Lilia \& Widodo, 2014).

Di samping itu penelitian yang dilakukan oleh Chonkaew, Sukhummek, \& Faikhamta (2016) juga menunjukkan bahwa kegiatan pembelajaran berbasis kehidupan nyata membantu siswa dalam menyadari pentingnya teori dan ilmu pengetahuan dalam pengelolaan sumber daya alam. Keingintahuan dan hasrat ingin tahu siswa berhasil dibangkitkan dengan cara menghubungkan informasi/proses di kehidupan nyata dengan informasi yang 
didapat dari sekolah (Sumarni, Wijayati, \& Supanti, 2019).

Penelitian yang lainnya dari Tuwoso, Putra, Mukhadis, Mahamad, \& Sembiring (2020) yang menggunakan sinkronisasi MOOC juga menyatakan MOOC yang dikembangkan layak dan menarik (skor rata-rata 92\%). Sehingga MOOCs yang dikembangkan dapat dijadikan acuan untuk pengembangan teknologi yang memiliki konten yang lebih dalam dan kompleksitas konten. Meskipun begitu, perlu juga mempertimbangkan empat indicator, yaitu kondisi ekonomi, kondisi sosial, kondisi individu, dan kondisi lingkungan.

Dari keempat penelitian yang sudah disebutkan di atas dapat menjadi suatu kesimpulan bahwa implementasi pembelajaran berbasis kehidupan (lifebased learning) dapat dinyatakan memiliki potensi yang sangat signifikan untuk dikembangkan serta diterapkan. Mulai dari pemanfaatan MOOCs atau LMS atau penggunaan metode praktikal juga dapat diimplementasikan dalam pembelajaran berbasis kehidupan. Hal ini dikarenakan adanya pembelajaran ini memberikan kesempatan pada pebelajar untuk menjadi manusia seutuhnya, apalagi untuk zaman sekarang ini yang sudah didukung oleh perkembangan TIK yang semakin pesat, sehingga pembelajaran ini dapat memberikan otonomi tersendiri bagi pebelajar.

\section{KESIMPULAN}

Perkembangan teknologi yang semakin pesat telah menjadikan adanya berbagai perubahan di segala bidang. Hal ini semakin berkembang pesat berkat dampak positif dari penyebaran virus korona yang menjadikan segala aspek kehidupan perlu mendapatkan "sokongan" teknologi digital. Perubahan ini juga berlaku pada bidang pendidikan. Pebelajar sebagai orang yang belajar dituntut untuk siap menghadapi berbagai perkembangan zaman di masa yang akan datang. Di samping itu, pebelajar sekarang merupakan generasi yang bisa dikatakan lebih "cerdas" dibandingkan dengan generasi sebelumnya. Karena mereka telah dapat mengoperasikan berbagai macam sumber-sumber yang terkadang sulit untuk digunakan oleh generasi sebelumnya. Proses belajar mengajar yang cenderung kaku sudah tidak bisa membendung generasi yang "hebat" ini. Maka dari itu, diperlukan suatu pembelajaran yang dapat memenuhi kebutuhan mereka serta dapat membangun personalisasi belajarnya yang variatif. Untuk itu, penulis menelaah pembelajaran berbasis kehidupan (life-based learning) yang dapat mendukung kebutuhan pebelajar yang dinamis. Pebelajar dapat belajar tidak hanya dari dalam kelas saja, namun juga dapat belajar di mana saja serta kapan saja yang sesuai dengan apa yang dikehendakinya. Pebelajar dapat belajar melalui variasi sumber belajar maya yang ada, seperti MOOCs, LMS, Media Sosial dan lain sebagainya. Di samping itu, adanya pembelajaran ini juga memberikan kesempatan pada mereka untuk lebih banyak meluangkan waktu di luar pendidikan formal, sehingga membentuk pengalaman belajarnya secara bermakna. Sehingga mereka dapat mengkonstruksi pengetahuannya secara mandiri dengan mendayagunakan berbagai sumber belajar yang ditemuinya. Harapannya dari tulisan ini dapat menjadi bacaan alternatif bagi pengajar dalam mengembangkan pembelajaran berbasis kehidupan untuk mendukung kebutuhan pebelajarnya.

\section{DAFTAR PUSTAKA}

Anagün, S. S. (2018). Teachers' Perceptions about the Relationship between 21st Century Skills and Managing Constructivist Learning Environments. International Journal of Instruction, 11(4), 825-840.

Andayani, Y., Al-Idrus, S. W., \& Purwoko, A. A. (2019). Penerapan Metode Praktikum Berbasis Kehidupan Seharihari Terhadap Keterampilan Proses 
Sains Siswa Kelas XI MIA MAN 1 Mataram. Chemistry Education Practice, 1(2), 20-26.

Baturay, M. H. (2015). An Overview of the World of MOOCs. Procedia - Social and Behavioral Sciences, 174, 427-433. doi: 10.1016/j.sbspro.2015.01.685

Bazelais, P., \& Doleck, T. (2018). Blended learning and traditional learning: A comparative study of college mechanics courses. Education and Information Technologies, 23(6), 2889-2900. doi: 10.1007/s10639-018-9748-9

Byers, T., Imms, W., \& Hartnell-Young, E. (2018). Evaluating teacher and student spatial transition from a traditional classroom to an innovative learning environment. Studies in Educational Evaluation, 58, 156-166. doi: 10.1016/j.stueduc.2018.07.004

Chonkaew, P., Sukhummek, B., \& Faikhamta, C. (2016). Development of analytical thinking ability and attitudes towards science learning of grade-11 students through science technology engineering and mathematics (STEM education) in the study of stoichiometry. Chemistry Education Research and Practice, 17(4), 842-861.

Chukwuere, J. E., \& Chukwuere, P. C. (2017). The impact of social media on social lifestyle: A case study of university female students. Gender and Behaviour, 15(4), 9966-9981.

Cooper, H. M. (1998). Synthesizing research: A guide for literature reviews (Vol. 2). Sage.

Degeng, I. N. S. (1998). Mencari Paradigma Baru Pemecahan Masalah Belajar dari Keteraturan Menuju Kesemrawutan.
Makalah disajikan dalam Pidato Pengukuhan Guru Besar IKIP Malang.

Fedyk, M., \& Xu, F. (2018). The epistemology of rational constructivism. Review of Philosophy and Psychology, 9(2), 343-362.

Fink, A. (2019). Conducting Research Literature Reviews: From the Internet to Paper. Los Angeles: SAGE Publications.

Gagne, R. M. (1985). The Conditions of Learning and Theory of Instruction (Subsequent edition). New York: Wadsworth Pub Co.

Guri-Rosenblit, S. (2009). Distance education in the digital age: Common misconceptions and challenging tasks. International Journal of E-Learning \& Distance Education/Revue internationale $d u$ e-learning et la formation à distance, 23(2), 105-122.

Hidayat, W. N., Patmanthara, S., Sari, R. K., \& Sutikno, T. A. (2019). Cognitive ability improvement in learning resource development course through implementation of life-based learning models using LMS. Journal of Physics: Conference Series, 1193(1), 012034. IOP Publishing.

Jumaat, N. F., Tasir, Z., Halim, N. D. A., \& Ashari, Z. M. (2017). Project-based learning from constructivism point of view. Advanced Science Letters, 23(8), 7904-7906.

Kastur, A., \& Riyanto, Y. (2020). Feasibility of Developing Direct Learning Models With a Life Based Learning Approach. IJORER: International Journal of Recent Educational Research, 1(3), 261-270.

Kompas Cyber Media. (2019, Mei 15). APJII: Jumlah Pengguna Internet di 
Indonesia Tembus 171 Juta Jiwa. Diambil 9 Mei 2021, dari KOMPAS.com website: https://tekno.kompas.com/read/2019/05 /16/03260037/apjii-jumlah-penggunainternet-di-indonesia-tembus-171-jutajiwa

Kuswandi, D., Setyosari, P., Hutkemri, H., Suryati, N., Chusniyah, T., Diana, R. C., \& Nurdiansa, E. S. (2020). Development Of Life-Based Curriculum Model Designs In The Global Era. Proceeding on International Conference of Science Management Art Research Technology, 1(1), 26-32.

Lase, D. (2019). Pendidikan di Era Revolusi Industri 4.0. SUNDERMANN: Jurnal Ilmiah Teologi, Pendidikan, Sains, Humaniora dan Kebudayaan, 1(1), 28-43.

Lilia, L., \& Widodo, A. T. (2014). Implementasi pembelajaraan kontekstual dengan strategi percobaan sederhana berbasis alam lingkungan siswa kelas X. Jurnal Inovasi Pendidikan Kimia, 8(2).

Mershad, K., \& Wakim, P. (2018). A learning management system enhanced with internet of things applications. Journal of Education and Learning, 7(3), 23-40.

Praherdhiono, H. (2019). Konstruksi Belajar Berbasis Kehidupan pada MOOCs. Dalam Teori dan Implementasi Teknologi Pendidikan: Era Belajar Abad 21 dan Revolusi Industri 4.0. Malang: Seribu Bintang.

Praherdhiono, H., Adi, E. P., \& Prihatmoko, Y. (2018). Konstruksi demokrasi belajar berbasis kehidupan pada implementasi LMS dan MOOC. Edcomtech Jurnal
Kajian Teknologi Pendidikan, 3(1), 2128.

Praherdhiono, H., Adi, E. P., \& Prihatmoko, Y. (2020). Implementasi Heutagogy Melalui Konstruksi Pembelajaran Personal (sistem pengelolaan pembelajaran di era pandemi dan masa depan). Dalam Implementasi Pembelajaran Di Era Dan Pasca Pandemi Covid-19. Malang: Seribu Bintang.

Praherdhiono, H., Sulton, M., Lioe, A. T., \& Hammad, J. (2017). Open Learning Systems for Learners with Capabilities as Innovators at State University of Malang. International Conference on Learning Innovation (ICLI 2017). Atlantis Press.

Prasetiawan, I. B. (2012, September). Keberaksaraan Informasi (Information Literacy) bagi SDM Pengelola Perpustakaan di Era Keterbukaan Informasi. Diambil dari http://eprints.rclis.org/17553/

Ratnawati, D., \& Setuju, S. (2019). Revitalization of Occupational Safety and Health Teaching Materials Based on Life Based Learning Paradigms. TAMAN VOKASI, 7(2), 210. doi: $10.30738 /$ jtv.v7i2.6319

Selwyn, N. (2014). Education and 'the digital.' British Journal of Sociology of Education, 35(1), 155-164. doi: $10.1080 / 01425692.2013 .856668$

Setyosari, P. (2017). Menciptakan pembelajaran yang efektif dan berkualitas. Jinotep (jurnal inovasi dan teknologi pembelajaran): kajian dan riset dalam teknologi pembelajaran, 1(1), 20-30. 
Shaffer, D. W. (2008). Education in the digital age. Nordic Journal of Digital Literacy, 3(01), 39-52. doi: 10.18261/ISSN1891-943X-2008-01-04

Staron, M. (2011a). Connecting and integrating life based and lifewide learning. Dalam Learning for a Complex World: A Lifewide Concept of Learning, Education and Personal Development. AuthorHouse.

Staron, M. (2011b). Life-based learning model-a model for strength-based approaches to capability development and implications for personal development planning. Mindful Creations, February, 1-14.

Sulton. (2019). Kapabilitas Pebelajar dalam Transdisiplin. Dalam Teori dan Implementasi Teknologi Pendidikan: Era Belajar Abad 21 dan Revolusi Industri 4.0. Malang: Seribu Bintang.

Sulton, Adi, E. P., \& Susilo, H. (2017, Oktober). Curriculum Model of Capability Development through Transdisciplinary Courses System. 197202. Atlantis Press. doi: 10.2991/icli17.2018 .38

Sumarni, W., Wijayati, N., \& Supanti, S. (2019). Analisis Kemampuan Kognitif Dan Berpikir Kreatif Siswa Melalui Pembelajaran Berbasis Proyek Berpendekatan Stem. J-Pek (Jurnal Pembelajaran Kimia), 4(1), 18-30.

Suryati, N., Kuswandi, D., Setyosari, P., Chusniyah, T., Diana, R. C., \& Nurdiansa, E. S. (2020). Curriculum Development of Postgraduate Study Program Based on Life-Based Learning Philosophy and Disruption Technology. 1st International Conference on
Information Technology and Education (ICITE 2020), 434-436. Atlantis Press.

Thaariq, Z. Z. A. (2020). The Use of Social Media as Learning Resources to Support the New Normal. Teknodika, 18(2), 8093.

Theys, S. (2017). Constructivism. International relations theory.

Tuwoso, Putra, A. B. N. R., Mukhadis, A., Mahamad, A. K. B., \& Sembiring, A. I. (2020). Development of MOOCs synchronized life-based learning to improve the quality of outcomes in prospective vocational teachers in the era of education 4.0. Journal of Physics: Conference Series, 1456, 012051. doi: 10.1088/1742-6596/1456/1/012051

Tynjälä, P. (1999). Towards expert knowledge? A comparison between a constructivist and a traditional learning environment in the university. International Journal of Educational Research, 31(5), 357-442. doi: 10.1016/S0883-0355(99)00012-9

Yueh, H.-P., \& Hsu, S. (2008). Designing a learning management system to support instruction. Communications of the ACM, 51(4), 59-63.

Herdiana, D. (2020). Konstruksi Konsep Social Distancing dan Lockdown dalam Perspektif Kebijakan Publik. Jurnal Inovasi Pembangunan: Volume, 8 No. 02 (107-107).

Iqbal, M., Latifah, S., \& Irwandani, I. (2019). Pengembangan Video Blog (Vlog) Channel Youtube Dengan Pendekatan Stem Sebagai Media Alternatif Pembelajaran Daring. Jurnal Inovasi Pembangunan Vo,ume 7 No.2 (135-135). 


\section{Halaman Kosong}

